\title{
Diagnosing companies in financial difficulty based on the auditor's report
}

\author{
Robert Zenzerović ${ }^{1,{ }^{*}}$ and Martin Valić-Vale ${ }^{2}$ \\ ${ }^{1}$ Faculty of economics and tourism "Dr. Mijo Mirković", \\ Juraj Dobrile University of Pula \\ Preradovićeva 1, 52100 Pula, Croatia \\ E-mail: 〈robert.zenzerovic@unipu.hr〉 \\ ${ }^{2}$ Riviera Adria d.d. \\ Ul. Vladimira Nazora, 52440, Porě \\ E-mail: 〈martin.valic-vale@riviera.hr
}

\begin{abstract}
The approach used in this paper expands on existing research that focuses on devising prediction models for companies experiencing financial difficulties and which in turn serves as a criteria-based diagnosis tool for distinguishing healthy companies from those facing seriously financial difficulties. It draws on auditors' reports on company financial statements that emphasize a company's ability to continue as a going concern as the main criterion used to distinguish companies experiencing financial difficulties from companies that are not. Two closely-related hypotheses were tested in this paper. First, the authors tested the hypothesis that an auditor's report accompanied by an explanatory paragraph pointing out issues associated with the going concern assumption is the proper criterion for differentiating companies experiencing financial difficulties from those that are not. Second, the central assumption that is tested relates to a combination of financial ratios whereby authors presume that an appropriate combination of financial ratios is a good analytical tool for distinguishing companies experiencing serious financial difficulties from those that are not. Research results conducted among 191 companies listed on the Zagreb Stock Exchange confirm both hypotheses. The LRA model - a diagnosis tool for identifying companies with financial problems, was also derived using logistic regression analysis. The statistical adequacy and quality of the model was tested using measures like Nagelkerke R2, type 1 and type 2 errors that appear when calculating the classification ability of the model. All measures indicated that model was statistically sufficient and validated its use as a diagnosis tool in recognizing the companies facing financial difficulties.
\end{abstract}

Key words: diagnosis of financial difficulties, auditor reports, logistic regression analysis

Received: September 26, 2014; accepted: March 31, 2016; available online: April 04, 2016

DOI: $10.17535 /$ crorr.2016.0010

* Corresponding author. 


\section{Introduction}

Forecasting the financial stability or instability of a business is always a current topic. It becomes a researcher's particular focus during times of economic crisis - and noticing that forecasting financial stability or instability is subject to cyclical effects, just like national economies.

Research on financial (in)stability forecast focuses on historical data as the basis for estimating model(s) that present an acceptable level of classification and accuracy, and consequently are a good diagnostic tool for financial (in)stability. Past experience provides the basis for make future decisions. In that regard, financial (in)stability model(s) are not only oriented towards the past, but are tools for prognosis of future financial health.

Most research on diagnosing financial (in)stability and prognosis enables researchers to derive models that distinguish stable companies from those experiencing financial difficulties based on whether a company is faced with bankruptcy (or not), to what extent is it paying off its due debts and other financial characteristics that are drawn from financial reports. This paper employs another approach that distinguishes financial stable companies from those facing serious financial difficulties based on the auditors' opinion on companies' financial statements. The second chapter elaborates on previous studies, and subsequently, chapter three presents research methodology and two main hypotheses. Chapter four presents research results together with an estimation model and the indicators of a quality model.

\section{Previous studies}

Diagnosis and prediction of financial instability dates from the period when loans were first given out, regardless of whether in the form of monies or goods. During the evolution of business relationships, lending money became more sophisticated and included various (quantitative and qualitative) financial and nonfinancial inputs. The scientific approach to researching financial (in)stability began after the Great Depression in 1930s thirties when simpler models existed. The application of quantitative statistical methods began some 20 years later with univariate statistics [3]. The biggest impulse for applying a more complex statistical method known as multiple discriminant analysis was given by Edward I. Altman, who developed the Z-score model using data from U.S. companies [2] - the most cited financial (in)stability model in the literature [24]. Among the other authors most cited in literature who used similar techniques are Deakin, Ohlson, Edmister and Kralicek.

Contemporary research in predicting financial instability uses increasingly sophisticated statistical techniques like logistic regression analysis, multidimensional scaling, survival analysis, decision trees, neural networks, 
fuzzy rules based analysis, cumulative sum models, chaos theory, linear goal programming, multi-criteria decision aid approach, rough set analysis, expert systems, self-organizing maps, etc. [25].

Research has uncovered that country-specific models provide poor classification when applied to companies from other countries. This is particularly true in situations when the model was developed using data from a company operating in a developed country and applied to a company operating in a less developed economic environment [19]. The recommendation then is to develop and use a model designed using the data from the host country as it includes much of the particular economic and related variables specific for the economic environment that is analyzed. Škeljo [19] has shown that the Altman Z-score did not perform well in transitional countries such as Croatia. Šarlija [18] has developed a credit scoring model for small companies using various statistical techniques and was among the first to neural networks for developing credit scoring models in the Croatian business environment. Šarlija [17], in her later works with Šorić, Vlah and Vojvodić Rosenzweig, used logistic regression and multicriteria decision making in credit scoring. Šarlija, Penavin and Harc [16] have developed a model that forecasts short term (one year) insolvency from data provided by companies operating in Croatia. Streitenberger, M. and Miloš Sprčić [15] have conducted research to find financial ratios that best distinguish companies regularly defaulting on their liabilities as opposed to those that remain solvent. Another relevant insolvency prediction model was developed by Pervan and Filipović [13] using the financial data of companies meeting their liabilities within 90 days of the maturity date, and those that do so after 90 days. A similar model was developed by Novak and Crnković [11] who utilised a bank's experience with clients in order to classify clients into categories of good, medium and bad. Zenzerović [23], [24] have used logistic regression analysis to develop models for estimating the going concern assumption for companies of various sizes. Last but not least, important work was carried out by Belak and Aljinović Barać [6]. They have developed a business excellence model using data from listed companies that suggests six levels of business excellence. As given above, most of this research has been directed towards company bankruptcy or a company's inability to settle its liabilities prior to maturity as a main criterion for discriminate financially stable from unstable companies.

\section{Formulation of a theoretical model - hypothesis and methodology}

A scientific approach to predicting financial (in)stability begins with the study of economic and financial theory which is the basis of the theoretical model. The authors of this research place their focus on new criterion - the auditor's report. 
For the purpose of this research the selected company was viewed as unstable if the auditor issued an explanatory paragraph in the report pointing out that there existed substantial doubt about company's ability to continue as a going concern. This meant that the auditor asserted as questionable the company's ability to continue operating without needing to significantly reducing its operations or to continue operating at all in next 12 months. This leads to the first hypothesis requiring testing: $\mathrm{H}_{1}$ - the auditor's report accompanied by an explanatory paragraph pointing out the issues relating to the going concern assumption is an appropriate criterion for classifying the company as financially unstable. The second hypothesis is subsequently tested if the first is validated as true. It is presented as follows: $\mathrm{H}_{2}-$ a combination of financial ratios are a good analytical tool for distinguishing companies experiencing serious financial difficulties from those that are not.

Having defined the theoretical model, research then focused on data collection. Research was performed on companies listed on the Zagreb Stock Exchange. The sample included financial statements along with auditor reports for 191 companies from the nonfinancial sector for the year 2009. The sample was divided in two subsamples. The first included financial statements of 22 companies for which the auditor report with explanatory paragraph that point out the problems with going concern assumption was issued. Companies included in this subsample are viewed as financially unstable. The second subsample covered the financial statements of 169 companies that did not have an explanatory paragraph referring to the going concern assumption in the auditor's report. The reason the authors selected the year 2009 is that it was the first year of the recession in the Republic of Croatia with a decline in BDP of $6.9 \%$, leading to an expected higher proportion of opinions on the going concern assumption.

For each company, 28 financial ratios were calculated. The financial ratios included liquidity ratios (3), solvency ratios (4), activity (3) and profitability ratios (9), cash flow ratios (8) and economic value added.

The research methodology incorporated two closely-related statistical methods. To test hypothesis $\mathrm{H}_{1}$, simple descriptive statistics was used that included group mean comparisons and onward carried arithmetic mean and standard deviation analysis. Testing hypothesis $\mathrm{H}_{2}$ required applying a more sophisticated statistical method known as logistic regression analysis. It is a form of regression analysis used when the dependent variable is a dichotomy and the independent variables are of any type. The dependent variable were dichotomous, where a value of 0 is given to financially unstable companies (where the auditor's report included an explanatory paragraph pointing out the problems associated with the going concern assumption), whereas those viewed as financially stable (no explanatory paragraph on the going concern assumption 
in the auditor's report) had a value of 1 . The independent variables were the abovementioned 28 financial ratios.

Logistic regression is used to predict a dependent variable on the basis of continuous and/or categorical independents and to determine the percentage of variance in the dependent variable as given by the independents. It also used to rank the relative importance of independents, assess interaction effects, and to understand the impact of covariate control variables [8]. The advantages it provides are primarily its robustness as is evident in the following:

- Logistic regression analysis does not assume linear relations between dependent and independent variables;

- Logistic regression analysis does not assume normally distributed variables;

- The subsamples or groups in the sample could possibly be of different sizes;

- Logistic regression analysis does not assume homoscedasticity [24].

The logarithmic form of the logistic regression function is given by equation 1. $[9]$

$$
L_{i}=\ln \left(\frac{P_{i}}{1-P_{i}}\right)=\beta_{0}+\beta_{1} X_{1}+\beta_{2} X_{2}+\ldots+\beta_{n} X_{n}
$$

This form is transformed by antilogarithming giving equation 2 [9], which in turn are used to calculate the prognostic probability of financial problems appearing in the prediction model. The prognostic probability is the probability that there is a low possibility of financial difficulties occurring in a company. Logically, this raises the following question: When should a company be treated as having a low appearance or no financial problems or vice versa? Generally, if the prognostic probability is higher than or equal to 0.5 , the company is viewed as having a low appearance of financial problems and vice versa.

$$
P_{i}=\frac{1}{1+e^{-\left(\beta_{0}+\beta_{1} X_{1}+\beta_{2} X_{2}+\ldots+\beta_{n} X_{n}\right)}}
$$

In the fourth step of the scientific approach to predicting the appearance of financial problems the estimation of statistical adequacy of the model is required. If the statistical parameters are appropriate, the model should be theoretically examined once more (the fifth step), and it can be used on real world cases. If the parameters indicate that the model is not statistically adequate, it should be theoretically reformulated and the scientific approach starts from beginning again [24]. 


\section{Research results}

The central part of the research is the analysis of research results in order to test the hypothesis. The first hypothesis reads as follow: An auditor's report accompanied by an explanatory paragraph pointing out the problems with the going concern assumption is the appropriate criterion for classify whether a company is faced with financial difficulties. This is tested using the group means analysis.

Table 1 shows the group means of companies with no financial difficulties and those facing financial difficulties i.e. for two subsamples. Research results clearly indicate that there is a significant difference between independent variables (financial ratios) of companies with and without financial difficulties, where the distinction between them is done based on the auditor's report. Financially unstable companies were those in which the auditor has emphasised the problems related to liquidity, high indebtedness and negative profitability. According to research results, companies with financial difficulties i.e. their financial statements are accompanied by an auditor's report with an explanatory paragraph pointing out problems with the going concern assumption have significantly worse values of ratios than those without financial difficulties, i.e. those where no emphasis on problems with the going concern assumption was made. The t-test of differences in means is conducted on each of the 27 input variables from the auditor's report, with the results are shown in Table 1. It is evident from Table 1 that a significant difference in means (at a $10 \%$ level) between the financially stable group and the financially unstable group of companies was found in 17 of the 27 input variables. This proves the first hypothesis. Consequently, the hypothesis that an auditor's report accompanied by an explanatory paragraph pointing out the problems with the going concern assumption is an appropriate criterion for classifying whether a company is faced with financial difficulties is confirmed and the research proceeds to testing hypothesis $\mathrm{H} 2$.

Hypothesis H2 - Combination of financial ratios represent a good analytical tool for distinguishing companies experiencing serious financial difficulties from those that are not which is tested using the logistic regression analysis as explained previously. Logistic regression analysis starts with analysing the statistical relation of 28 financial ratios - independent variables which show if companies are facing with financial difficulties. According to the assumption of no multicollinearity which has to be fulfilled, correlated independent variables were omitted as well as statistically insignificant variables. The backward stepwise method was used to omit correlated independent variables. The final result comes from logistic regression analysis and is a logistic regression function given by Equation 3, where the characteristic of independent variables are shown in Table 2. 


\begin{tabular}{|c|c|c|c|c|c|c|}
\hline \multirow{2}{*}{ Financial ratios / Companies } & \multicolumn{2}{|c|}{ With financial problems } & \multicolumn{2}{|c|}{ Without financial problems } & \multirow{2}{*}{$\begin{array}{l}\text { T-test of } \\
\text { differences } \\
\text { in means }\end{array}$} & \multirow{2}{*}{$\begin{array}{c}\text { Difference } \\
\text { significan } \\
\mathrm{t} \text { at the } \\
10 \% \text { level } \\
\end{array}$} \\
\hline & Mean & Std. Deviation & Mean & Std. Deviation & & \\
\hline $\begin{array}{c}\text { Short term assets/Short } \\
\text { term liabilities }\end{array}$ & 0.6211 & 0.7743 & 1.6823 & 2.7104 & 0,0349 & yes \\
\hline $\begin{array}{c}\text { Cash and cash } \\
\text { equivalents/Short term } \\
\text { liabilities } \\
\end{array}$ & 0.0834 & 0.1948 & 0.6092 & 1.7814 & 0,0846 & yes \\
\hline $\begin{array}{c}\text { Working capital/Total } \\
\text { assets } \\
\end{array}$ & -0.364 & 0.3998 & 0.03818 & 0.2226 & 0 & yes \\
\hline Total debt/Total assets & 0.8536 & 0.3375 & 0.4522 & 0.2251 & 0 & yes \\
\hline EBIT/Interests' costs & -200.8159 & 932.412 & 3.6392 & 15.5989 & 0,021 & yes \\
\hline $\begin{array}{c}\text { Total debt/(Retained } \\
\text { earnings+Depreciation) }\end{array}$ & 0.356 & 18.4602 & 4.3085 & 14.0617 & 0,1172 & no \\
\hline $\begin{array}{c}\text { Retained earnings/Total } \\
\text { assets }\end{array}$ & -0.3126 & 0.4407 & -0.0094 & 0.2498 & 0 & yes \\
\hline \begin{tabular}{|l|} 
Total revenues/Total assets \\
\end{tabular} & 0.4960 & 0.392 & 0.5607 & 0.51 & 0,2837 & no \\
\hline Sales/Accounts receivables & 6.6883 & 10.7352 & 6.3941 & 7.4276 & 0,4345 & no \\
\hline $\begin{array}{c}365 /(\text { Sales/Accounts } \\
\text { receivables })\end{array}$ & 2232.6977 & 9961.7425 & 612.4318 & 4227.7358 & 0,0849 & yes \\
\hline $\begin{array}{c}\text { Total revenues/Total } \\
\text { expenses }\end{array}$ & 0.75322 & 0.1833 & 0.998 & 0.3844 & 0,019 & yes \\
\hline Sales/Costs of sales & 0.8335 & 0.1885 & 1.0275 & 0.4222 & 0,0175 & yes \\
\hline $\begin{array}{l}\text { Revenues from financing } \\
\text { activities/Expenses from } \\
\text { financing activities } \\
\end{array}$ & 0.2562 & 0.469 & 1.6633 & 6.8026 & 0,1672 & no \\
\hline EBI/Total revenues & -6.4228 & 29.021 & -0.0179 & 0.4216 & 0,001 & yes \\
\hline EBIT/Total revenues & -6.4194 & 29.0218 & -0.012 & 0.4242 & 0,002 & yes \\
\hline Net sales/Total revenues & -0.2876 & 0.4926 & -0.0654 & 0.414 & 0,0108 & yes \\
\hline Return on assets (ROA) & -0.1157 & 0.2149 & 0.0222 & 0.052 & 0 & yes \\
\hline \begin{tabular}{|c|} 
Return on common equity \\
(ROCE)
\end{tabular} & -0.71789 & 1.1347 & 0.1053 & 0.5305 & 0 & yes \\
\hline \begin{tabular}{|c|} 
(Cash flow from \\
operations+interests+tax)/I \\
nterests \\
\end{tabular} & 0.0136 & 2.7707 & 8.7969 & 36.16 & 0,1286 & no \\
\hline $\begin{array}{c}\text { Cash flow from } \\
\text { operations/Total liabilities }\end{array}$ & -0.0843 & 0.242 & 0.3328 & 2.137 & 0,1813 & no \\
\hline $\begin{array}{c}\text { Cash flow from } \\
\text { operations/Short term } \\
\text { liabilities }\end{array}$ & -0.1026 & 0.2783 & 0.5329 & 2.3057 & 0,0995 & yes \\
\hline \begin{tabular}{|c|} 
(Cash flow from \\
operations+interests +tax $) /$ \\
EBIT \\
\end{tabular} & -1.2767 & 5.7056 & 2.5733 & 14.5154 & 0,1102 & no \\
\hline $\begin{array}{c}\text { Cash flow from } \\
\text { investments/(Cash flow } \\
\text { from operations }+ \text { financing } \\
\text { activities) } \\
\end{array}$ & -0.7865 & 1.4226 & -0.8871 & 1.8516 & 0,4032 & no \\
\hline $\begin{array}{c}\text { Cash flow from } \\
\text { investments/Cash flow from } \\
\text { financing activities }\end{array}$ & 4.0204 & 20.28845 & -109.3774 & 1391.4496 & 0,3517 & no \\
\hline $\begin{array}{c}\text { Cash flow from } \\
\text { operations }+ \text { interests }+ \text { tax }) / \\
\text { Total assets } \\
\end{array}$ & 0.0038 & 0.1224 & 0.0697 & 0.1094 & 0,0047 & yes \\
\hline $\begin{array}{c}\text { Cash flow from } \\
\text { operations/Equity }\end{array}$ & -0.096 & 0.5447 & 0.3244 & 1.0677 & 0,0357 & yes \\
\hline Economic value added & -55016.948 .7381 & 49985736.0281 & -52253188.6706 & 178050053.134 & 0,4712 & no \\
\hline
\end{tabular}

Table 1: Group means for financially stable and unstable companies 
The logistic regression model given in Equation 3 includes five independent variables. Two of them are solvency ratios (Total debt/Total assets and Retained earnings/Total assets), two are profitability ratios (Return on assets and Return on common equity) and one is the cash flow ratio (Cash flow/Total assets).

$L R A=\frac{1}{1+e^{-(5,758-5,241 T D / T A+1,707 R E / T A+13,841 R O A+1,573 R O C E+9,089 C F / T A)}}$

\begin{tabular}{|l|c|c|c|c|c|c|}
\hline & B & S.E. & Wald & df & Sig. & Exp(B) \\
\hline $\begin{array}{l}\text { Total debt/Total assets } \\
\text { TD/TA) }\end{array}$ & -5.241 & 1.726 & 9.218 & 1 & 0.002 & 0.005 \\
\hline $\begin{array}{l}\text { Retained earnings/Total } \\
\text { assets (RE/TA) }\end{array}$ & 1.707 & 0.778 & 4.810 & 1 & 0.028 & 5.511 \\
\hline ROA & 13.841 & 6.544 & 4.474 & 1 & 0.034 & 1026326.572 \\
\hline ROCE & 1.573 & 1.319 & 1.423 & 1 & 0.233 & 4.822 \\
\hline $\begin{array}{l}\text { (Cash flow from } \\
\text { operations+interests+tax)/ } \\
\text { Total assets (CF/TA) }\end{array}$ & 9.089 & 4.107 & 4.899 & 1 & 0.027 & 8858.534 \\
\hline Constant & 5.758 & 1.208 & 22.711 & 1 & 0.000 & 316.804 \\
\hline
\end{tabular}

Table 2: Characteristics of independent variables

The quality of the logistic regression model is tested using the HosmerLemeshow test. A high significance of the Hosmer-Lemeshow test (0.994) indicates that the hypothesis for a difference between real and prognostic values of dependent variables is acceptable i.e. the model is statistically adequate. Another quality indicator is Nagelkerke R2 which evaluates goodness of fit for the model. According to statistical analysis, Nagelkerke R2 indicates that the LRA model explains $61.3 \%$ of variations confirming the representativeness of the LRA model.

\begin{tabular}{|r|c|r|r|r|r|}
\hline -2 Log & Cox \& Snell & Nagelkerke & \multicolumn{3}{|c|}{ Hosmer-Lemeshow Test } \\
\cline { 4 - 6 } likelihood & $\mathrm{R}^{2}$ & $\mathrm{R}^{2}$ & Hi square & $\mathrm{df}$ & Significance \\
\hline 63.909 & 0.321 & 0.613 & 1.406 & 8 & 0.994 \\
\hline
\end{tabular}

Table 3: The quality coefficient of the LRA model

Another approach to testing the statistical adequacy model is to analyse its classification ability. Classification results from the LRA model (Table 4) show that the model correctly classify $91.7 \%$ of companies included in the sample. The theory usually considers model classification ability as acceptable when it correctly classifies more than $62.5 \%$ of companies, hence the model classification ability can be estimated as being relatively high [9]. The overall model classification ability should be broadened and examined in more detail. 
Specifically, the overall classification results included in statistics are two wellknown types of errors: type 1 error and type 2 error. Type 1 error occurs in situations where the model is classifying a financially unstable company as a stable one, while type 2 error appears in opposite situations i.e. when the model classifies financially stable companies as unstable. In classification error analysis, the occurrences of type 1 errors are less eligible because misclassifying a financially unstable company as a stable one most often results in significant additional costs than the costs incurred in the case of a financially stable company characterized as being unstable which is type 2 error. According to model classification results, type 1 error occurs in $31.8 \%$ of cases (or 7 cases as shown in Table 4) while type 2 error appears in only $5.1 \%$ (or 8 cases as shown in Table 4). The most probable explanation of the relatively high occurrence of type 1 error is that the explanatory paragraph in the auditor's report is issued not only in cases when a company exhibits poor financial indicators, but also in some situations when financial ratios remain acceptable. In other words, there are some cases when auditors point out problems with the going concern assumption based on certain qualitative explanatory variables that will influence a company's financial difficulties in the near future. The identification and influence of the qualitative independent variables could very well be the focus of future research and further development of this model.

\begin{tabular}{|l|l|c|c|c|}
\hline \multirow{2}{*}{ Real state of financial difficulties } & \multicolumn{3}{|c|}{ Predicted state of financial s difficulties } \\
\cline { 3 - 4 } & Financial problems & $\begin{array}{c}\text { Percentage of } \\
\text { correct } \\
\text { classification }\end{array}$ \\
\cline { 3 - 4 } & YES & NO & 68.2 \\
\hline Financial difficulties & YES & 15 & 7 & 94.9 \\
\cline { 2 - 4 } & NO & 8 & 150 & 91.7 \\
\hline \multicolumn{3}{|l|}{ Overall classification accuracy in \% } \\
\hline
\end{tabular}

a. The cut value is 0.650

Table 4: Classification results of the LRA model

The abovementioned quality measures indicate that the LRA model can be used as a tool for diagnosing the financial health of companies by potential investors, customers, suppliers, creditors, employees and other stakeholders. Auditors could find this approach interesting when estimating a company's ability to continue as a going concern keeping in mind the approach used in this research. 


\section{Conclusion}

This paper extends existing research such that it uses the auditor's report on the financial statements of companies that points out a company's ability to continue as a going concern as the main criterion to distinguish companies experiencing serious financial difficulties from those that are not. The research results confirm the first hypothesis i.e. they validate the approach used. The authors suggest that auditors are among the few external stakeholders most familiar with a company's financial health. Auditing standards stipulate that auditors publicly disclose whether a company is experiencing difficulties in its ability to continue as a going concern, hence their reports are, or should be, a valuable source of information. Research results indicate that the combination of financial ratios is a good analytical basis for distinguishing companies experiencing serious financial difficulties from those that are not. The combination of five financial ratios that best distinguish companies experiencing serious financial problems from those that are not includes two solvency ratios, two profitability ratios and a cash flow ratio. This combination, represented as the LRA model, has shown a high degree of statistical adequacy, making it an appropriate diagnosis tool when estimating a company's financial health. Despite its wide scope of application, analysts should direct their attention to the type 1 error i.e. the model's incorrect classification of companies experiencing serious financial difficulties into the group of companies that are not. The authors consider this a consequence of the criterion used for distinguishing companies experiencing serious financial difficulties from companies that are not. Specifically, pointing out the ability of a company to proceed as a going concern could possibly be noted in the auditor's report as a consequence of some qualitative variable that does not exert an immediate influence on a quantitative or financial variable. Consequently, the derived LRA model classifies the company into the group of companies that are not experiencing financial difficulties, though in fact the company is unstable considering the auditor added an explanatory paragraph in the audit report. This opens up new questions that should be addressed scientifically. For instance, what qualitative variables/measures influence a company's ability to continue as a going concern and what is the direction and degree of their influence; or is it possible to calculate not only two degrees of financial stability, but multiple levels of financial stability. No matter what the answers are to the previous questions, the complexity and stochastic character of economics as a field of social sciences will always require the attention of professional judgment based on experience as well as intuition which should be intensively utilised when deciding whether a company is stable or not.

Possibly the main criticisms of the research and its results in this paper might be the size of the subsample of companies experiencing financial 
difficulties. However, this is reflected in the situation for the selected year involving the biggest companies in Republic of Croatia which have or should have the highest possible quality of financial statements. In future work, the derived model should be tested in order to gain more insight into its classification ability and the subsample extended to check and improve the conclusions drawn from this paper.

\section{References}

[1] Altman, I. E. (2000). Predicting financial distress of companies: Revisiting the Zscore and ZETA® models, adapted and updated by: Heine, L.M. prof. Available at: http://pages.stern.nyu.edu/ ealtman/PredFnclDistr.pdf [Accessed on March 1, 2013].

[2] Altman, E. I. (1968). Financial ratios, discriminant analysis and the prediction of corporate bankruptcy. The Journal of Finance, 23(4), 589-609.

[3] Beawer, W. H. (1966). Financial ratios as a predictors of failure, empirical research in accounting: Selected studies. Supplement to Journal of Accounting Research, 4, 71-111.

[4] Becchetti, L. and Sierra, J. (2003). Bankruptcy risk and productive efficiency in manufacturing firms. CEIS Tor Vergata - Research Paper Series, 2003(30).

Available at: ftp://www.ceistorvergata.it/repec/rpaper/No-30-

Becchetti, Jaime.pdf [Accessed on March 15, 2013].

[5] Belak, V. (2003). Računovodstvo dodane vrijednosti (Value added accounting), RRiF, No. 12/2003, 18.-25.

[6] Belak, V. and Aljinović Barać, Ž. (2007). Business excellence (BEX) indeks - za procjenu poslovne izvrsnosti tvrtki na tržištu kapitala u Republici Hrvatskoj (Business excellence index - an index for estimating the business excellence of a companies on the Croatian capital market). RRiF, No. 10/2007, 15-25.

[7] Fawcett, T. (2006). An introduction to ROC analysis. Pattern Recognition Letters, $27,861-874$.

[8] Garson, D, (2008). Logistic regression. Available at: http://faculty. chass.ncsu.edu/garson/PA765/discrim.htm [Accessed on March $15,2013]$.

[9] Hair, F. J., Anderson, R. E., Tatham, R. L. (1987). Multivariate Data Analysis. Macmilin Publishing Company, 2nd edition, New York.

[10] Novak, B. (2003). Predviđanje poslovnih teškoća banka u Republici Hrvatskoj na osnovi javno dostupnih financijskih pokazatelja (Prognosis of business problem in banks in the Republic of Croatia on the basis of publicly disclosed financial ratios), Ekonomski pregled (Economic Review), 54(11-12), 904-924.

[11] Novak, B. and Crnković, I. (2007). Klasifikacija dužnika banke prema razini poslovnih problema na osnovi podataka iz osnovnih financijskih izvješća (Classification of bank clients according to the level of financial problems and based on data from financial reports), Ekonomski pregled (Economic Review), 58(1-2), 4771.

[12] Novak, B. and Sajter, D. (2006). Mora li stečaj biti i "smrt" trgovačkog društva? Odgovori Europske unije i Hrvatske (Should bankruptcy mean the end of a 
company? Answers from EU and Croatia), XXVII. Wissenschaftliches Symposium "Wie real ist ein Europa der zwei Geschwindigkeiten", Osijek, Croatia.

[13] Pervan, I. and Filipović, D. (2010). FP RATING® - model za predviđanje (in)solventnosti poslovnih partnera (FP rating - the insolvency prediction model), RRiF, 7/10, 92-96.

[14] Rozga, A. (2007). Multivarijantna analiza (Multivariate Analysis), Script, Ekonomski fakultet Split (Faculty of Economics in Split), Split, Croatia.

[15] Streitenberger, M. and Miloš Sprčić, D. (2011). Prediktivna sposobnost financijskih pokazatelja u predviđanju kašnjenja u otplati kredita (Predictive ability of financial ratios in predicting defaulting on loan payment), Ekonomski pregled (Economic Review), 62(7-8), 383-403.

[16] Šarlija, N., Penavin, S. and Harc, M. (2009). Predviđanje nelikvidnosti poduzeća u Hrvatskoj (Prediction of company insolvency in Croatia), Zbornik Ekonomskog fakulteta u Zagrebu (Proceedings of Faculty of Economics in Zagreb), 2, 21-36.

[17] Šarlija, N., Šorić, K., Vlah, S. and Vojvodić Rosenzweig, V. (2009). Logistic regression and multicriteria decision making in credit scoring, Proceedings of the 10th International Symposium on Operational Research SOR '09, 175.-184., Nova Gorica, Slovenia.

[18] Šarlija, N. (2003). Modeli kreditnog rizika u ocjenjivanju kreditne sposobnosti malih poduzetnika (Credit scoring models in estimating creditworthiness of small enterprises), Ekonomski fakultet Zagreb (Faculty of Economics in Zagreb), doctoral dissertation, $239 \mathrm{p}$.

[19] Škeljo, K. (2000). Istraživanje mogućnosti primjene Altmanovog modela u hrvatskom gospodarstvu (Research on possibility of applying the Altman model in the Croatian economy), master thesis, Ekonomski fakultet u Zagrebu (Faculty of Economics in Zagreb).

[20] Škeljo, K. (2001). Statistički modeli ranog upozorenja na poslovnu krizu (Statistical models of early warning to a business crisis). RRiF, 4/2001, 75-80.

[21] Vitezić, N. (2006). Predviđanja stečaja i indikatori ranog upozorenja (Bankruptcy prediction and red flags). XLI. simpozij Financijsko restrukturiranje profitnog i neprofitnog sektora u Hrvatskoj (XLI Symposium on the Financial Restructuring of the Profit and Non-profit sector in Croatia), 195-202.

[22] Zenzerović, R. and Peruško, T. (2006). Kratki osvrt na modele za predviđanje stečaja (Short retrospection on credit scoring models), Ekonomska istraživanja (Economic Research), 19(2), 132-151.

[23] Zenzerović, R. (2009). Business' financial problems prediction - Croatian experience, Ekonomska istraživanja (Economic Research), 20(4), 1-16.

[24] Zenzerović, R. (2011). Credit scoring models in estimating the creditworthiness of small and medium and big enterprises. Croatian Operational Research Review, Split, Croatia, 2(1), 143-157.

[25] Zenzerović, R., Černe, K., Peruško, T., Kostešić, S., Štifanić, E. (2012). Računovodstvena obzorja (Accounting Horizons), Hrvatska zajednica računovođa financijskih djelatnika - Udruženje računovođa i financijskih djelatnika Istre (Croatian association of accountants and financial officers - Society of accountants and financial officers in Istria), Pula, Croatia ISBN: 978-953-57214-0-6. 